\title{
Synthesizing and Characterizing the Hybrid Pigment Fe 0.7 Cr1.3 03 With High NIR Reflectance for Sustainable Energy Saving Applications
}

\section{Research Article}

Keywords:

Posted Date: February 18th, 2021

DOI: https://doi.org/10.21203/rs.3.rs-218989/v2

License: (c) (1) This work is licensed under a Creative Commons Attribution 4.0 International License.

Read Full License 


\section{Abstract}

The authors have requested that this preprint be withdrawn due to erroneous posting.

\section{Full Text}

The authors have withdrawn this preprint from Research Square. 